\title{
SKRINING SENYAWA FITOKIMIA RUMPUT LAUT Sargassum sp. DAN AKTIVITASNYA SEBAGAI ANTIBAKTERI TERHADAP Staphylococcus aureus dan Eschericia coli
}

\author{
Phytochemical Compound Screening of Sargassum sp. and It's Activity \\ as Antibacterial Against Staphylococcus aureus and Escherichia coli \\ Indria Eka Pangestuti, Sumardianto dan Ulfah Amalia \\ Program Studi Teknologi Hasil Perikanan \\ Fakultas Perikanan dan Ilmu Kelautan, Universitas Diponegoro \\ Jl. Prof. Soedarto, SH, Tembalang, Semarang, Jawa Tengah - 50275, Telp/fax. +6224 747698 \\ Email: indriaekap@yahoo.com
}

Diserahkan tanggal 2 Desember 2016, Diterima tanggal 11 Januari 2017

\begin{abstract}
ABSTRAK
Bakteri S. aureus dan E. coli merupakan bakteri patogen yang sering menjadi masalah pada produk makanan terutama pada produk perikanan, sehingga diperlukan senyawa antibakteri yang efektif untuk menghambat pertumbuhannya. Rumput laut Sargassum sp. memiliki senyawa bioaktif yang dapat berfungsi sebagai senyawa antibakteri, seperti flavonoid, saponin, tannin, dan fenol. Tujuan dari penelitian ini adalah untuk mengetahui kandungan fitokimia pada ekstrak rumput laut Sargassum sp. dan mengetahui pengaruh penambahan konsentrasi terhadap pertumbuhan bakteri S. aureus dan E. coli. metode yang digunakan pada penelitian ini adalah eksperimental laboratoris dengan menggunakan model Rancangan Acak Lengkap (RAL). Parameter pengujian yang dilakukan adalah uji fitokimia kuantitatif ekstrak rumput laut Sargassum sp. dan zona hambat ekstrak rumput laut Sargassum sp. menggunakan metode difusi sumur dengan penambahan konsentrasi $0 \%, 5 \%, 10 \%, 15 \%$ dan dilakukan 3 kali ulangan. Data hasil uji zona hambat dianalisis menggunakan uji ANOVA (Analysis Of Varians) dan Beda Nyata Jujur (BNJ). Hasil uji fitokimia kuantitatif ekstrak rumput laut

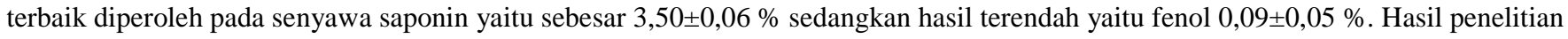
zona hambat menggunakan metode difusi sumur menghasilkan diameter pada bakteri $S$. aureus berkisar 1,527 $\pm 0,326 \mathrm{~mm}$ sampai $6,323 \pm 0,27 \mathrm{~mm}$, sedangkan diameter pada bakteri E.coli berkisar $0 \pm 0 \mathrm{~mm}$ sampai $3,58 \pm 0,33 \mathrm{~mm}$. Berdasarkan hasil tersebut, penambahan konsentrasi ekstrak rumput laut Sargassum sp. memberikan pengaruh terhadap diameter zona hambat bakteri $S$. aureus dan E. coli.
\end{abstract}

Kata kunci: Rumput Laut Sargassum sp., Fitokimia, Antibakteri, Staphylococcus aureus, dan Eschericia coli

\section{ABSTRACT}

S. aureus and E. coli bacteria is a pathogenic bacteria that often cause problems in food products especially in fishery products, so that an effective antibacterial compound is needed to inhibit their growth. Sargassum sp. seaweed has a bioactive compound that can be functioned as antibacterial compound, such as flavonoid, saponin, tannin, and phenol. The aim of this research was to know the phytochemical content in Sargassum sp. seaweed extract and to know the effect of concentration added to the S. aureus and E. coli bacteria growth. This research was using experimental laboratories method with Completely Randomized research Design (CRD). The conducted testing parameter were Quantitative Phytochemical Analysis and Inhibition Zone on Sargassum sp. seaweed extract using diffusion well method with 0\%, 5\%, 10\%, and 15\% added concentration for triplicates. The inhibition zone's data were analyzed using ANOVA (Analysis of Variance) and Honestly SignificaNt Difference (HSD). The best quantitative phytochemical results of seaweed extract was found in the saponin compound which was 3,50 $\pm 0,06 \%$ while the lowest was found in phenol which was $0,09 \pm 0.05 \%$. The inhibition zone research results using diffusion well method resulted on the S. aureus bacteria's diameter

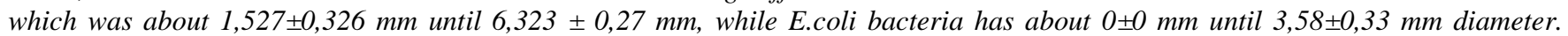
Based on the research results above, the concentration addition of Sargassum sp. seaweed extract gave effect to the inhibition zone's diameter of $S$. aureus and E. coli bacteria.

Keywords: Sargassum sp. Seaweed, Phytochemical, Antibacterial, Staphylococcus aureus, and Eschericia coli

\section{PENDAHULUAN}

Rumput laut Sargassum sp. memiliki kandungan senyawa bioaktif dan berpotensi sebagai antibakteri. Menurut penelitian yang dilakukan oleh Septiana dan Ari (2012), tentang fisikokimia ekstrak rumput laut coklat Sargassum duplicatum diperoleh hasil bahwa secara kualitatif semua ekstrak S. duplicatum mengandung flavonoid, saponin, tannin, 
dan terpenoid dalam jumah yang hampir sama. Menurut penelitian yang dilakukan oleh Sastry dan Rao (1994), Sargassum sp. memiliki kandungan $\mathrm{Mg}, \mathrm{Na}, \mathrm{Fe}$, tanin, iodin dan fenol yang berpotensi sebagai bahan antimikroba terhadap beberapa jenis bakteri patogen. Antibakteri adalah produk metabolik yang dihasilkan suatu organisme tertentu, yang dalam jumlah tertentu bersifat merusak atau menghambat mikroorganisme lain. Dengan perkataan lain, antibakteri merupakan zat kimia yang dihasilkan oleh suatu mikroorganisme yang menghambat mikroorganisme lain (Pelczar dan Chan, 2008).

Badan Standarisasi Nasional (BSN) memiliki kebijakan mempersyaratkan mutu pangan, salah satunya adalah cemaran mikrobiologi. Misalnya untuk beberapa produk olahan perikanan seperrti naget, sosis, siomay, otak-otak, mempersyaratkan keberadaan $S$. aureus maksimal $1 \times 10^{2}$ koloni/g, sedangkan abon dan ikan asap mempersyaratkan maksimal 1 x $10^{3}$ koloni/g. keberadaan bakteri Eschericia coli pada semua produk yaitu $<3 \mathrm{APM} / \mathrm{g}$. Pemilihan bakteri $S$. aureus dan E. coli ini karena berdasarkan pengamatan terhadap Standar Nasional Indonesia (SNI).

\section{METODE PENELITIAN}

\section{Materi Penelitian}

Sampel yang digunakan dalam penelitian ini adalah rumput laut Sargassum sp. yang diperoleh dari UD. Rumput Laut Mandiri, Gunungkidul. Pelarut yang digunakan pada ekstraksi adalah metanol, etil asetat, dan n-hexan. Bakteri $S$. aureus FNCC 0047 dan E. coli FNCC 0091 merupakan bakteri yang digunakan untuk uji aktivitas antibakteri. Alat yang digunakan yaitu, rotary evaporator merek Eyela SB-1100, Inkubator, hotplate, autoclave, Laminar Air Flow, vortex, petri merek Herma, jarum ose.

\section{Penelitian Tahap I}

Rumput laut Sargassum sp kering digiling menjadi bentuk serbuk kemudian diekstraksi dengan metode maserasi. Perbandingan sampel dengan pelarut yaitu 1:4 (b/v). (Alamsyah et al., 2014). Setelah proses maserasi selama 24 jam, maka ekstrak disaring menggunakan kertas saring Whatman, dan pelarut diuapkan menggunakan alat rotary evaporator pada suhu $40{ }^{\circ} \mathrm{C}$. Pengujian fitokimia secara kuantitatif mengacu pada Harbone (1987) meliputi uji flavonoid, saponin, tanin, dan fenol.

\section{Pengujian Fenol (Harbone ,1987)}

Sampel sebanyak $5 \mathrm{~g}$ dilarutkan dalam $100 \mathrm{ml}$ aquades, kemudian disentrifuge untuk memisahkan endapan dan filtrat. Selanjutnya $1 \mathrm{ml}$ kemudian ditambahkan 0,5 ml Folin Denis (folin 1:1) dan $1 \mathrm{ml}$ larutan $\mathrm{NaCO}_{3}$ jenuh, kemudian didiamkan selama 10 menit. Larutan selanjutnya ditambahkan aquadest hingga volume $10 \mathrm{ml}$ dan divortex hingga homogen dan dibaca absorbansinya menggunakan spektrofotometer dengan panjang gelombang $730 \mathrm{~nm}$. Hasil yang diperoleh dihitung dengan menggunakan kurva standar yang dibuat dengan menggunakan phenol. Kadar kandungan fenol dalam persen dinyatakan dalam rumus:

$$
\begin{aligned}
& \% \text { kadar fenol }=\mathrm{x} . \text { faktor pengencer } \mathrm{x} 100 \% \\
& \text { Berat Sampel }(\mathrm{mg})
\end{aligned}
$$

\section{Pengujian Flavonoid}

Sampel sebanyak $5 \mathrm{~g}$ dilarutkan dalam $100 \mathrm{ml}$ aquades. Larutan dipisahkan endapan dan filtrat. Filtrat diambil $1 \mathrm{ml}$ kemudian ditambahkan $3 \mathrm{ml}$ larutan $\mathrm{AlCl}_{3} 5 \%$, dan aquadest hingga volume $10 \mathrm{~mL}$, divortex sampai homogen. Larutan yang sudah homogen kemudian dibaca absorbansinya menggunakan spektrofotometer dengan panjang gelombang $420 \mathrm{~nm}$. Hasil yang diperoleh dihitung dengan menggunakan kurva standar yang dibuat dengan menggunakan Quercetin. Kadar kandungan flavonoid dalam persen dinyatakan dalam rumus:

$\%$ Kadar Flavonoid = x. faktor pengencer $\mathrm{x} 100 \%$ Berat Sampel (mg)

\section{$\mathrm{x}=$ Absorbansi larutan standar}

\section{Pengujian Tanin}

Sampel sebanyak $5 \mathrm{~g}$ dilarutkan dalam $100 \mathrm{ml}$ aquades. Larutan disentrifuge untuk memisahkan endapan dan filtrat. Filtrat diambil $1 \mathrm{ml}$ kemudian ditambahkan $0,5 \mathrm{ml}$ folin denis (folin 1:1) dan $1 \mathrm{ml}$ larutan $\mathrm{NaCO}_{3}$ jenuh, kemudian didiamkan selama 10 menit. Larutan selanjutnya ditambahkan aquadest hingga volume $10 \mathrm{~mL}$ dan divortex hingga homogen. Larutan yang sudah homogen kemudian dibaca absorbansinya menggunakan spektrofotometer dengan panjang gelombang $730 \mathrm{~nm}$. Hasil yang diperoleh dihitung dengan menggunakan kurva standar yang dibuat dengan menggunakan Tanin acid murni. Kadar kandungan tanin dalam persen dinyatakan dalam rumus:

$\%$ Kadar Tanin $=\frac{\text { x. faktor pengencer } \mathrm{x} 100 \%}{\text { Berat Sampel }(\mathrm{mg})}$

$\mathrm{x}=$ Absorbansi larutan standar

\section{Prosedur pengukuran saponin}

Sampel sebanyak $5 \mathrm{~g}$ dilarutkan dalam $100 \mathrm{ml}$ aquades. Larutan tersebut ditambah $25 \mathrm{ml}$ Ethanol 75\% kemudian gojog hingga homogen. Setelah digojog kemudian didiamkan selama 30 menit hingga suspense mengendap. Larutan dipisahkan dengan endapannya dan dimasukkan ke dalam botol timbang kemudian dikering ovenkan hingga konstan. Berat akhir atau berat konstan ditimbang kemudian hitung kadar saponin.

$\%$ Kadar Saponin $=\underline{\text { Berat konstan }- \text { Berat krus }} \times 100 \%$

\section{source not found.}

Berat SampelError! Reference

\section{Penelitian Tahap II}

Penelitian Tahap II dilakukan dengan pengujian aktivitas antibakteri ekstrak rumput laut Sargassum sp. dengan metode difusi sumur. Perlakuan yang diberikan yaitu perbedaan konsentrasi yang diberikan pada sumuran. Konsentrasi yang digunakan yaitu $0 \%$ (kontrol), 5\%, 10\%, dan $15 \%$.

\section{Analisa Data}

Data yang diperoleh dari penelitian ini adalah hasil pengujian fitokimia dan hasil perhitungan diameter zona hambat pada uji aktivitas antibakteri dengan metode difusi sumur. Data hasil pengukuran diameter zona hambat dianalisis menggunakan metode analisa sidik ragam ANOVA, jika ada perlakuan yang berbeda maka dilanjutkan dengan uji Uji BNJ (Beda Nyata Jujur).

() Copyright by Saintek Perikanan (Indonesian Journal of Fisheries Science and Technology), ISSN : 1858-4748 


\section{HASIL DAN PEMBAHASAN}

\section{Rendemen Ekstrak Sargassum sp.}

Hasil ekstrak rumput laut Sargassum sp. menghasilkan ekstrak dalam bentuk pasta. Berikut adalah rendemen ekstrak rumput laut Sargassum sp. yang dapat dilihat pada Tabel 1.

Tabel 1. Rendemen Ekstrak Sargassum sp.

\begin{tabular}{|c|c|c|c|c|}
\hline $\mathbf{P}$ & $\begin{array}{l}\text { BE } \\
\text { (gr) }\end{array}$ & $\begin{array}{c}\mathbf{R} \\
(\%)\end{array}$ & B & $\mathbf{W}$ \\
\hline Methanol & 1,08 & 0,86 & Pasta & $\begin{array}{c}\text { Hijau } \\
\text { kehitaman }\end{array}$ \\
\hline Etil asetat & 0,96 & 0,77 & Pasta & $\begin{array}{c}\text { Hijau } \\
\text { kehitaman }\end{array}$ \\
\hline n-hexan & 0,83 & 0,66 & Pasta & $\begin{array}{c}\text { Hijau } \\
\text { kehitaman }\end{array}$ \\
\hline
\end{tabular}

Keterangan :

P : Pelarut

BE : Berat Ekstrak

$\mathrm{R} \quad$ : Rendemen

B : Bentuk

W : Warna

Tujuan penggunaan 3 pelarut yang berbeda yaitu pelarut metanol, etil asetat, dan n-hexan dengan kemurnian teknis adalah untuk menentukan jenis pelarut terbaik yang digunakan penelitian tahap selanjutnya. Proses ekstraksi rumput laut Sargassum sp., dilakukan menggunakan metode maserasi atau perendaman satu tahap. Pemilihan metode maserasi dikarenakan beberapa senyawa bioaktif atau fitokimia yang berfungsi sebagai senyawa antibakteri, seperti salah satu contohnya yaitu flavonoid sangat rentan mengalami kerusakan dan mudah teroksidasi pada suhu tinggi. Hal tersebut sejalan dengan penelitian yang dilakukan oleh Septiana dan Ari (2012), bahwa berdasarkan uji kelarutan ekstrak Sargassum duplicatum dalam beberapa pelarut diperoleh hasil pelarut yang menghasilkan kelarutan tertinggi diantara 3 pelarut metanol, etil asetat dan n-hexan adalah hasil kelarutan pada metanol. Nilai kelarutan pada metanol yaitu 39,86\%.

\section{Kandungan Fitokimia Ekstrak Sargassum sp.}

Ekstrak rumput laut Sargassum sp.yang telah diperoleh, diuji fitokimia secara kuantitatif guna mengetahui seberapa besar kandungan fitokimia yang terkandung pada ekstrak tersebut. Hasil pengujian fitokimia Sargassum sp. tersaji pada Tabel 2.

Tabel 2. Hasil Kandungan Fitokimia Ekstrak Sargassum sp.

\begin{tabular}{ccll}
\hline No. & Pelarut & Parameter & $\begin{array}{c}\text { Rata-rata }(\%) \pm \\
\text { Standar deviasi }\end{array}$ \\
\hline 1 & Methanol & Flavonoid & $0,17 \pm 0,006$ \\
& & Saponin & $3,50 \pm 0,06$ \\
& & Tannin & $0,25 \pm 0,03$ \\
2 & \multirow{2}{*}{ Etil Asetat } & Fenol & $0,09 \pm 0,05$ \\
& & Flavonoid & $0,10 \pm 0,01$ \\
& & Saponin & $2,43 \pm 0,03$ \\
3 & & Tannin & $0,21 \pm 0,02$ \\
& & Fenol & $0,08 \pm 0,005$ \\
& & Flavonoid & $0,08 \pm 0,002$ \\
& & Saponin & $1,66 \pm 0,03$ \\
& & Tannin & $0,15 \pm 0.005$ \\
& & Fenol & $0,06 \pm 0,004$ \\
\hline
\end{tabular}

Berdasarkan Tabel 5, diketahui bahwa hasil yang didapatkan pada penelitian tahap I ini yaitu bahwa pelarut metanol menghasilkan ekstrak dengan kandungan senyawa fitokimia tertinggi dibandingkan dengan pelarut etil asetat dan n-hexan, sehingga pada penelitian tahap II digunakan pelarut metanol untuk ekstraksi rumput laut Sargassum sp. Hal tersebut menunjukkan bahwa meanol memiliki kepolaran yang lebih tinggi dibandingkan dengan pelarut etil asetat dan nhexane. Semakin polar jenis pelarutnya semakin besar kandungan fitokimianya. Kandungan fitokimia tertinggi dalam ekstrak Sargassum sp. yaitu saponin. Hal tersebut dikarenakan saponin dan methanol memiliki kepolaran yang sama sehingga saponin mudah larut pada pelarut metanol. Menurut Suharto et al. (2012), saponin paling tepat diekstraksi dari tanaman dengan pelarut etanol $70-95 \%$ atau metanol. Ekstrak saponin akan lebih banyak dihasilkan jika diekstraksi menggunakan metanol karena saponin bersifat polar sehingga akan lebih mudah larut daripada pelarut lain.

Tinggi dan rendahnya senyawa fitokimia juga dipengaruhi oleh polaritas pelarut. Tinggi rendahnya kandungan senyawa fitokimia pada Sargassum sp. juga tergantung pada pelarut yang digunakan untuk proses ekstraksi. Beberapa penelitian sebelumnya menunjukkan bahwa pelarut methanol atau pelarut yang bersifat polar cenderung lebih efektif dalam menarik senyawa fitokimia. Menurut Septiana dan Ari (2012), hasil uji kualitatif menunjukkan bahwa metode ekstraksi tidak mempengaruhi kandungan flavonoid, saponin, maupun terpenoid. Hal ini diduga karena dalam berdasarkan strukturnya, flavonoid maupun saponin mempunyai bagian yang bersifat polar maupun non polar dengan bagian yang hampir sama. Seperti halnya flavonoid dan saponin, terpenoid mempunyai bagian polar dan non polar, tetapi bagian non polar pada terpenoid jauh lebih banyak dibandingkan bagian polar sehingga terpenoid cenderung lebih mudah larut dalam pelarut non polar.

\section{Aktivitas Antibakteri Ekstrak Sargassum sp.}

Hasil pengujian aktivitas antibakteri ekstrak rumput laut Sargassum sp. terhadap bakteri $S$. aureus dan E. coli tersaji pada Tabel 3.

Tabel 3. Hasil Pengujian Aktivitas Antibakteri Ekstrak Rumput Laut Sargassum sp. Terhadap Bakteri S. aureus

\begin{tabular}{ccc}
\hline $\begin{array}{c}\text { Konsentrasi } \\
\text { ekstrak }(\%)\end{array}$ & $\begin{array}{c}\text { Diameter Zona } \\
\text { hambat bakteri } \\
\text { S. aureus }(\mathbf{m m}) \\
\pm \text { standar deviasi }\end{array}$ & $\begin{array}{c}\text { Diameter Zona } \\
\text { hambat Bakteri } \\
\text { E. coli }(\mathbf{m m}) \pm \\
\text { standar deviasi }\end{array}$ \\
\hline $0 \%$ (kontrol) & $0,00^{\mathrm{a}}$ & $0,00^{\mathrm{a}}$ \\
$5 \%$ & $1,527 \pm 0,326^{\mathrm{b}}$ & $0,00^{\mathrm{a}}$ \\
$10 \%$ & $3,410 \pm 0,22^{\mathrm{c}}$ & $1,75 \pm 0,36^{\mathrm{b}}$ \\
$15 \%$ & $6,323 \pm 0,27^{\mathrm{d}}$ & $3,58 \pm 0,33^{\mathrm{c}}$ \\
\hline
\end{tabular}

Berdasarkan Tabel 6 diketahui bahwa pada bakteri $S$. aureus dan $E$. coli terbentuk zona hambat terbesar terdapat pada konsentrasi ekstrak 15\%. Kedua hasil tersebut menunjukkan bahwa semakin besar konsentrasi ekstrak Sargassum sp. yang ditambahkan, maka akan semakin besar nilai diameter zona hambat yang terbentuk. Berdasarkan hasil uji aktivitas antibakteri dengan mengukur zona hambat menggunakan metode difusi sumur, diameter zona hambat bakteri $S$. aureus lebih besar dibandingkan diameter zona hambat pada bakteri E. coli. Hal ini disebabkan oleh struktur dinding sel pada kedua bakteri tersebut berbeda. Bakteri $S$.

(ㄷ) Copyright by Saintek Perikanan (Indonesian Journal of Fisheries Science and Technology), ISSN : 1858-4748 
aureus merupakan salah satu bakteri gram positif, sedangkan bakteri $E$. coli merupakan salah satu bakteri gram negatif. Dinding sel pada bakteri gram positif terdiri dari peptidoglikan yang tebal, sedangkan pada bakteri gram negatif terdiri dari peptidoglikan yang tipis. Peptidoglikan memiliki sifat polar sehingga mudah ditembus oleh senyawa antibakteri dari Sargassum sp. yang cenderung bersifat polar. Dinding sel bakteri gram negatif sebagian besar tersusun oleh membrane lipid di bagian terluar membran, sehingga melapisi peptidoglikan yang terletak di bawah membran lipid tersebut. Membran lipid bersifat non polar sehingga susah ditembus oleh senyawa antibakteri pada Sargassum sp. yang cenderung bersifat polar. Menurut Brooks et al. (2007), bahwa lapisan selubung sel yang terdapat di antara membran sitoplasma dan kapsul disebut dinding sel. Dinding sel pada bakteri gram negatif terdiri dari peptidoglikan dan membran luar. Dinding sel berperan penting sebagai proteksi terhadap tekanan osmotik internal yang mencapai 5-20 atm dan juga berperan dalam pembelahan sel. Pernyataan Brooks et al. (2007) diperkuat oleh Fauzi et al. (2008), bahwa membran luar ini merupakan suatu lipid bilayer dengan protein, lipoprotein, dan polisakarida membrane luar bakteri gram negatif berhubungan dengan lingkungan termasuk pejamu manusia. Variasi pada membran luar inilah yang menyebabkab terdapatnya perbedaan patogenitas dan resistensi antimikroba, sedangkan menurut Nuria et al. (2009), susunan dinding sel bakteri gram negatif sangat kompleks. Sebagian besar bakteri gram negatif mempunyai kompleks lipopolisakarida pada dinding sek yaitu Lipid A, rantai pendek gula, dan rantai panjang karbohidrat yang disebut sebagai antigen $\mathrm{O}$ yang berfungsi mencegah penetrasi senyawa hidrofilik ke dalam membrane sel, sedangkan penetrasi zat hidrofilik seperti fenol dan tannin ke dalam membrane sel dicegah oleh lipid yang dimilikinya.

Berdasarkan uji aktivitas antibakteri menggunakan metode difusi sumur dengan menghitung zona hambat yang terbentuk, hasil yang diperoleh yaitu zona hambat yang terbentuk berada pada kisaran 5-10 $\mathrm{mm}$ berdasarkan penggolongan kekuatan antibakteri. Hasil diameter zona hambat terbesar pada bakteri $S$. aureus adalah $6,32 \pm 0,27 \mathrm{~mm}$ pada konsentrasi $15 \%$, sedangkan zona hambat terbesar pada

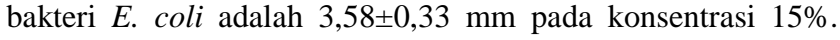
Diameter zona hambat yang terbentuk pada bakteri $S$. aureus berkisar antara $1,53 \pm 0,326 \mathrm{~mm}$ sampai $6,32 \pm 0,27 \mathrm{~mm}$, sedangkan diameter zona hambat yang terbentuk pada bakteri

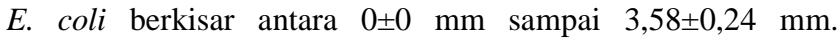
Berdasarkan hasil tersebut dapat disimpulkan bahwa senyawa antibakteri pada Sargassum sp. dalam menghambat pertumbuhan bakteri $S$. aureus dan E. coli tergolong rendah hingga sedang. Menurut Davis dan Stout (1971), ketentuan antibakteri adalah sebagai berikut; daerah hambatan $\geq 20 \mathrm{~mm}$ sangat kuat, daerah hambatan 10-20 mm berarti kuat, 5-10 mm sedang, dan daerah hambatan $\mathbf{5} \mathrm{mm}$ lemah.

Mekanisme Penghambatan Bakteri S. aureus dan E. coli Oleh Senyawa Bioaktif.Sargassum sp.

Mekanisme penghambatan bakteri S. aureus dan E. coli yang dilakukan oleh setiap senyawa antibakteri berbeda-beda. Pada umumnya senyawa antibakteri dapat menghambat pertumbuhan suatu bakteri dengan merusak beberapa bagian sel bakteri $S$. aureus dan $E$. coli, misalnya seperti perusakan membran sel, perusakan protein yang melapisi membran sel, mengganggu kerja DNA atau RNA, serta merusak membran sel. Senyawa bioaktif yang terdapat pada rumput laut Sargassum sp. adalah flavonoid, saponin, tanin, dan fenol. Senyawa yang dominan dari keempat senyawa tersebut yaitu senyawa saponin. Mekanisme kerja senyawa saponin yaitu dengan cara mengganggu permeabilitas sel yang menyebabkan senyawa intraseluler seperti sitoplasma akan keluar dan mengakibatkan kematian sel. Hal tersebut diperkuat oleh Nuria et al. (2009), bahwa mekanisme kerja saponin sebagai antibakteri adalah menurunkan tegangan permukaan sehingga mengakibatkan naiknya permeabilitas atau kebocoran sel dan mengakibatkan senyawa intraseluler akan keluar. Pernyataan Nuria et al (2009) diperkuat oleh Cavalieri et al. (2005), bahwa senyawa ini berdifusi melalui membran luar dan dinding sel yang rentan, lalu mengikat membran sitoplasma dan mengganggu dan mengurangi kestabilan itu. Hal ini menyebabkan sitoplasma bocor keluar dari sel yang mengakibatkan kematian sel. Agen antimikroba yang mengganggu membran sitoplasma bersifat bakterisida.

Rumput laut Sargassum sp. tidak hanya memiliki kandungan saponin. Kandungan senyawa bioaktif yang lain yaitu flavonoid, tannin, dan fenol, dimana mekanisme kerja dari senyawa tersebut berbeda tetapi semua senyawa bioaktif tersebut bersifat sidal. Senyawa bioaktif yang bersifat bakteriosidal yaitu senyawa yang dapat merusak pertahanan dan organ tubuh bakteri yang menyebabkan kerusakan sel dan pada akhirnya menyebabkan kematian pada bakteri yang diserang. Menurut pendapat Nikham dan Taty (2012), mekanisme kerja antimikroba adalah menghambat biosintesis dinding sel, meningkatkan permeabilitas membrane sel, dan mengganggu sintesis protein sel, sehingga menghambat pertumbuhan atau menyebabkan kematian sel bakteri. Umumnya, antimikroba yang mempengaruhi pembentukan dinding sel atau permebilitas membrane sel bekerja sebagai bakteriosidal, sedangkan yang mempengaruhi sintesis protein bekerja sebagai bakteriostatik.

\section{KESIMPULAN}

Kandungan fitokimia yang mendominasi adalah kandungan saponin yaitu 3,5\%, kandungan tanin 0,25\%, kandungan flavonoid $0,17 \%$, dan kandungan fenol sebesar $0,09 \%$. Zona hambat bakteri $S$. aureus dan E. coli yang ditambahkan ekstrak rumput laut Sargassum sp. diperoleh nilai $\mathrm{P}<5 \%$, hal tersebut dapat disimpulkan bahwa penambahan ekstrask Sargassum sp. berpengaruh nyata terhadap pertumbuhan kedua bakteri tersebut.

\section{UCAPAN TERIMA KASIH}

Penulis mengucapkan terima kasih kepada Ibu Laras Rianingsih, S.Pi., M.Sc atas masukan dan saran terhadap penelitian ini.

\section{DAFTAR PUSTAKA}

Alamsyah, H. K., Ita W., Agus S. 2014. Aktivitas Antibakteri Ekstrak Rumput Laut Sargassum cinereum (J.G. Agaradh) Dari Perairan Pulau Panjang Jepara Terhadap Bakteri Eschericia coli dan Staphylococcus 
Skrining Senyawa Fitokimia Rumput Laut dan Aktivitasnya sebagai Antibakteri terhadap Staphylococcus Aureus dan Eschericia Coli

epidermidis. Journal Of Marine Research, 3(2) : 6978

Brooks, G. F., Butel, J. S., Morse S. A. 2007. Mikrobiologi Kedokteran, Jawetz, Melnick \& Adelberg. Terjemahan Staf Pengajar Mikrobiologi FK Unair dari Medical Microbiology. Jakarta : EGC.

Cavalieri, S.J., I.D. Rankin., R.J. Harbeck., R.S. Sautter., Y.S. McCarter., S.E. Sharp., J.H. Ortez., dan C.A. Spiegel.2005. Manual of Antimicrobial Susceptibility Testing. USA: American Society for Microbiology.

Davis, W.W., dan T. R. Stout. 1971. Disc Plate Method of Microbiological Antibiotic Assay. Applied Microbiology. 22: $659-665$.

Fauzi, A.S., Kasper, D.L., Longo, D.L, Braunwald, E., Hauser, S,L., Jameson, J.L., dan Loscalzo, Joseph. 2008. Harrison's Principles of Internal

Harbone. 1987. Metode Fisika : Penuntun Cara Modern Menganalisis Tumbuhan Edisi II. Terjemah Kosasih Padmawinata dan Iwang Soediro. Penerbit ITB, Bandung.

Nikham dan Taty E.B. 2012. Uji Baku Antibakteri dari Buah Mahkota Dewa (Phaleria Macrocarpa (Scheff) Boerl)
Hasil Iradiasi Gamma dan Antibiotik Terhadap Bakteri Patogen. Dalam : Prosiding Pertemuan Ilmiah Ilmu Pengetahuan dan Teknologi Bahan. Serpong, pp. 168-174

Nuria, M. C., Faizaitun, A., Sumantri. 2009. Uji Aktivitas Antibakteri Ekstrak Etanol Daun Jarak Pagar (Jatropha Curcas L) Terhadap Bakteri Staphylococcus Aureus ATCC 25923, Escherichia Coli ATCC, Dan Salmonella Typhi ATCC 1408, Mediagro, 5(2):26-37.

Septiana, A. T. dan Ari A. 2012. Kajian Sifat Fisikokimia Ekstrak Rumput Laut Coklat Sargassum duplicatum Menggunakan Berbagai Pelarut dan Metode Ekstraksi. AGROINTEK. vol. 6:1

Suharto, M. Agung Pratama., Hoesa Jaya Edy., Jovie M. Dumanauw. (tt). Isolasi Dan Identifikasi Senyawa Saponin Dari Ekstrak Metanol Batang Pisang Ambon (Mussa paradisiaca var. sapientum L.). Program Studi Farmasi FMIPA UNSRAT, Manado. 